\title{
A genome-wide association study of calf birth weight in Holstein cattle using single nucleotide polymorphisms and phenotypes predicted from auxiliary traits
}

\author{
J. B. Cole ${ }^{\star 1}$ B. Waurich, $†$ M. Wensch-Dorendorf, $†$ D. M. Bickhart, ${ }^{*}$ and H. H. Swalve $†$ \\ ${ }^{*}$ Animal Improvement Programs Laboratory, Agricultural Research Service, USDA, Beltsville, MD 20705-2350 \\ †Institute of Agricultural and Nutritional Sciences, Martin-Luther-University Halle-Wittenberg, Theodor-Lieser-Str. 11, D-06120 Halle / Saale, \\ Germany
}

\section{ABSTRACT}

Previous research has found that a quantitative trait locus exists affecting calving and conformation traits on Bos taurus autosome 18 that may be related to increased calf birth weights, which are not routinely recorded in the United States. Birth weight data from large, intensively managed dairies in eastern Germany with management systems similar to those commonly found in the United States were used to develop a selection index predictor for predicted transmitting ability (PTA) of birth weight. The predictor included body depth, rump width, sire calving ease, sire gestation length, sire stillbirth, stature, and strength. Genetic and phenotypic correlations and heritabilities from the United States were substituted for the German values, and birth weight PTA predicted for 31,984 bulls with US genetic evaluations. A genome-wide association study was conducted on the predicted birth weight PTA with the 2-step genomic BLUP procedure used for routine evaluations in the United States. Allele substitution effects were predicted for 43,188 single nucleotide polymorphisms (SNP). Genotypes were available for 53,644 predictor animals. Gene set enrichment analysis was performed on the 100 SNP that had the largest effects expressed in additive genetic standard deviations. Several SNP related to growth and development were found among the 25 SNP with the largest effects, including markers located within or near ( $\leq 100 \mathrm{kbp})$ ABCA12, FLRT2, LHX4, MAP3K5, NRAC, NTNG1, PIGN, and ZNF75A. The gene set enrichment analysis identified the Kyoto Encyclopedia of Genes and Genomes "Regulation of actin cytoskeleton" pathway (bta04810) as being enriched. That pathway includes the $R O C K$ gene, which is involved in placental function in the human, as well as other developmental genes (e.g., FAK and PAK). Prediction equations

Received August 22, 2013.

Accepted January 28, 2014

${ }^{1}$ Corresponding author: john.cole@ars.usda.gov derived from one population are useful for identifying genes and gene networks associated with phenotypes that are not directly measured in a second population. This approach will identify only genes associated with the traits used to construct the birth weight predictor, and not loci that affect only birth weight.

Key words: birth weight, quantitative trait loci, selection index, single nucleotide polymorphism

\section{INTRODUCTION}

Many studies have reported on QTL affecting calving traits in several populations of Holstein cattle (Kühn et al., 2003; Schnabel et al., 2005; Holmberg and Andersson-Eklund, 2006; Kolbehdari et al., 2008; Thomasen et al., 2008; Seidenspinner et al., 2011; Purfield et al., 2014), and there appears to be a major gene on BTA18 affecting dystocia, stillbirth, conformation, and lifetime economic merit (Cole et al., 2009b; Brand et al., 2010; Sahana et al., 2011; Purfield et al., 2014). Qanbari et al. (2011) also identified a signature of selection in the same region of the cattle genome. Cole et al. (2009b) suggested that sequestration of leptin by a sialic acidbinding immunoglobulin-type lectin may result in increased gestation lengths and, in turn, increased calf birth weights.

Numerous studies have examined relationships among calving traits, including calving ease (CE), stillbirth (SB), gestation length (GL), and calf birth weight. The relationship of these traits has been known for some time, and Philipsson et al. (1979) discussed the importance of these interrelationships in the context of breeding strategies. Meijering (1984) surveyed the literature and reported correlations of $\mathrm{CE}$ and SB with birth weight ranging from 0.08 to 0.41 . Meyer et al. (2001) found that CE was negatively correlated with perinatal survival, meaning that increased dystocia was associated with decreased calf survival, and correlations were similar using data from first $(-0.16)$ and all $(-0.13)$ lactations. Correlations of direct $\mathrm{CE}$ and SB with direct GL of 0.18 and 0.38 , respectively, were reported for Danish Holsteins by Hansen et al. 
(2004). López de Maturana et al. (2009) used structural equation models to explore genetic relationships among dystocia, GL, and SB in US Holsteins, and reported significant but heterogeneous correlations among all 3 traits. More recently, Johanson et al. (2011) reported significant, positive genetic correlations of direct birth weight with direct dystocia (0.73), GL (0.52), and direct SB (0.57). Cole et al. (2009b) reported that genetic correlations among direct and maternal $\mathrm{CE}$ and $\mathrm{SB}$ differ when comparing whole-genome and chromosome 18-specific genetic marker effects.

Several recent studies have reported on QTL associated with birth weight. Eberlein et al. (2009) reported that the non-SMC condensin I complex, subunit G (NCAPG) gene on BTA6 is associated with fetal growth rates in Charolais cattle. Microsatellites on chromosomes 2, 6, and 14 had significant associations with birth weight in a Holstein $\times$ Jersey crossbred population (Maltecca et al., 2008). Markers associated with body size, CE, daily gain, and SB have been identified on BTA14 and BTA21 in German Fleckvieh (Pausch et al., 2011). These results lend support to the proposal of Cole et al. (2009b) that the QTL on BTA18 affecting calving and conformation traits may be associated with increased birth weight.

Calf birth weights are not routinely collected by US dairymen, although they are recorded in some experimental herds (Johanson and Berger, 2003; Olson et al., 2009; Heins et al., 2010). Birth weights are recorded in German contract test herds associated with the breeding organization Rinderzuchtverband MecklenburgVorpommern GmbH (Karow, Germany), which also use US sires and manage their herds similarly to American producers, suggesting that those data could be used to develop a predictor of sire PTA to be applied to both populations. The resulting birth weight data previously have been used for an unpublished genetic evaluation for calving traits as well as for analyses on the relationship of calving traits with conformation traits (Waurich et al., 2010) and for an assessment of the reliability of estimated birth weight in contrast to real weighing records (Waurich et al., 2011).

Selection index methodology (e.g., Cameron, 1997) can be used to identify the set of traits that best predict birth weight, and those predictors combined with population-specific genetic and phenotypic (co)variance matrices to produce correct weightings. The objectives of this study were to (1) develop a predictor for calf birth weight in the United States using correlated traits and data from similar herds in Germany, (2) use SNP markers to identify regions of the genome associated with birth weight, and (3) identify candidate genes located in genomic regions of interest that could have an effect on birth weight.

\section{MATERIALS AND METHODS}

\section{Prediction of Birth Weight Using EBV and Selection Indices}

Estimation of (Co)variances. Data for the estimation of variances and (co)variances needed for the selection index came from 20 contract herds of the breeding organization Rinderzuchtverband Mecklenburg-Vorpommern in northeastern Germany. The contract herd system initially was set up for the purpose of progeny testing and is now mainly used to collect additional data as a complement for the milk-recording data. All contract herds are relatively large by German standards, the average herd size is 780 cows, and recording of birth weights is mandatory. Considering the calving complex and first calvings only, data were recorded in the period of October 2005 to June 2010 and comprised 25,462 records on birth weight $(\mathrm{kg}), \mathrm{CE}$ ( 4 classes: 1 = without assistance, $2=$ little assistance, $3=$ heavy assistance, and $4=$ operation), GL (d) and SB status (0 or 1$)$. Calving ease records were recoded into a binary form such that class 1 was coded as 0 and all other classes as 1 . Calving data were merged with data on conformation scores stemming from the official classifications that use a linear 1 to 9 scale. In total, 14,022 records for dams of calves and 2,989 records on calves with a recorded calving and their later classification in first lactation could be used.

The fixed effects for calving traits, with the number of classes given in parentheses, were herd (20), yearseason (15), sex (2), and age at first calving (9). For conformation traits from the official classification, the fixed effects were herd (20), year-season (15), age at first calving (9), stage of lactation (5), and classifier (3).

Due to the different nature of the 2 trait complexes and the structure of the data used for the estimation of (co)variances, the variance components needed for the set-up of the selection index equations could not be estimated with 1 unique model. Rather, a series of models was used. A general overview of the models is given in Table 1. Essentially, bivariate sire-maternal grandsire models were used for the estimation of (co) variances among traits of the calving complex. Sirematernal grandsire models including direct additive and maternal genetic effects can be used as an alternative to animal models, as shown by Eaglen et al. (2012). Whereas birth weight and GL were treated as continuous traits using linear models, for the categorical traits $\mathrm{CE}$ and $\mathrm{SB}$, threshold models applying logit link and probit link functions were used. Both types of link functions were used, depending on the convergence of estimates. All bivariate runs for calving traits were 
done using ASReml 3.0 software (VSN International Ltd., Hemel Hempstead, UK). For the estimation of (co)variances between conformation traits and calving traits, all models were linear animal models including direct additive genetic as well as maternal genetic effects solved using VCE 6 software (Groeneveld et al., 2010). Finally, for (co)variances among the 4 conformation traits (not shown in Table 1), a multiple-trait sire model considering all 4 traits applying ASReml 3.0 was used. The series of models described in Table 1 provides far more (co)variance components than are needed for the selection index approach. For the selection index to be set up, only (co)variances between direct genetic effects are needed.

Selection Index Methodology. A selection index approach following Miesenberger (1997) was used to develop a predictor of sire (direct) birth weight using the following traits: sire dystocia, sire SB, sire GL, body depth (BDEP), rump width (RW), stature (STAT), and strength (STR). Trait definitions can differ slightly among countries, but even if phenotypes differ slightly across countries, it seems reasonable to assume that the underlying biology of those traits is the same if similar bull populations are used. Genetic correlations of US with German evaluations from the December 2012 Interbull (Interbull Center, Uppsala, Sweden) evaluation were positive and high for all traits evaluated: sire dystocia (0.81), sire SB (0.60), BDEP (0.81), RW (0.85), STAT (0.95), and STR (0.85). Neither Germany (vit, 2013) nor the United States (AIPL, 2013) currently provide routine genetic evaluations for GL. The relatively low genetic correlations for sire dystocia and sire SB may be due to differences in the genetic evaluation models used in Germany (vit, 2013) and the United States (Cole et al., 2007).

Using a traditional selection approach, an index (I) was used to predict the true value of the sire PTA for birth weight $(\mathbf{T})$ by regressing $\mathbf{T}$ on $\mathbf{I}$ :

$$
\mathbf{I}=b_{1} x_{1}+b_{2} x_{2}+\ldots+b_{n} x_{n}
$$

where the $b_{i}$ are regression coefficients and the $x_{i}$ are the PTA of the predictor traits included in $\mathbf{I}$. The predictors are selected to minimize the expectation of the squared difference between the true and predicted values by solving the normal equations for the index $\mathrm{Pb}=\mathrm{G}$ :

$$
\left[\begin{array}{ccc}
\sigma_{x_{1}}^{2} & \cdots & \sigma_{x_{1} x_{n}}^{2} \\
\vdots & \ddots & \vdots \\
\sigma_{x_{n} x_{1}}^{2} & \cdots & \sigma_{x_{n}}^{2}
\end{array}\right] \times\left[\begin{array}{c}
b_{1} \\
\vdots \\
b_{n}
\end{array}\right]=\left[\begin{array}{c}
\sigma_{u x_{1}} \\
\vdots \\
\sigma_{u x_{n}}
\end{array}\right],
$$

where the elements of $\mathbf{P}$ are the (co)variances among the predictors, $\mathbf{b}$ is a vector of regression coefficients, $\mathbf{G}$ is a vector of (co)variances among the predictors and $\mathbf{T}$, and the $\boldsymbol{\sigma}_{\mathrm{ui}}$ are the phenotypic (co)variances of the predictors with birth weight. However, when the predictors in $\mathbf{I}$ are PTA, the elements of $\mathbf{P}$ are genetic (co)variances that must be adjusted by the reliability of those PTA to calculate the elements of $\mathbf{b}$ without bias:

Table 1. Description of bivariate models used for estimation of (co)variances between calving traits1 (BW, CE, GL, and SB) and conformation traits (BDEP, STR, RW, and STAT) $)^{1,2}$

\begin{tabular}{lcccc}
\hline Trait $^{3}$ & Birth weight & CE & SB & GL \\
\hline Birth weight & LIN, S-MGS & LIN-BIN $_{\log }$ & LIN-BIN $_{\text {log }}$ & LIN-LIN \\
CE & S-MGS & BIN $_{\text {log }}$, S-MGS & LIN-BIN $_{\text {pro }}$ & LIN-BIN $_{\text {log }}$ \\
SB & S-MGS & S-MGS & BIN $_{\log }$, S-MGS & LIN-BIN $_{\log }$ \\
GL & S-MGS & S-MGS & & LIN, S-MGS \\
BDEP & & & \\
STR & LIN, $\mathbf{y}_{\text {cow }}=\mathbf{X b}+\mathbf{Z a}+\mathbf{e}$ & & \\
RW & LIN, $\mathbf{y}_{\text {calf }}=\mathbf{X b}+\mathbf{Z a}+\mathbf{Z} \mathbf{m}+\mathbf{e}$ & & \\
STAT & & & &
\end{tabular}

${ }^{1}$ The top block describes the bivariate models used to estimate (co)variances among the calving traits, with traits treated as linear (LIN) or binary traits (LIN-BINlog or LIN-BINpro; where log = logit link function, pro $=$ probit link function) above diagonal. Below and on the diagonal the model used for the random genetic effects is shown (S-MGS = sire-maternal grandsire model).

${ }^{2}$ The lower block describes the two bivariate models used to estimate (co)variances of calving traits with conformation traits. $\mathbf{y}_{\text {cow }}$ and $\mathbf{y}_{\text {calf }}$ are vectors of phenotypes for calving and conformation, and the subscript indicates calving traits recorded as observations on the calf ("calf") or the dam ("cow"); $\mathbf{X}$ and $\mathbf{Z}$ are design matrix relating observations to levels of fixed and random effects; $\mathbf{b}$ is a matrix of solutions for levels of fixed effects; $\mathbf{a}$ is a vector of random additive animal effects; $\mathbf{m}$ is a vector of random maternal genetic effects; and $\mathbf{e}$ is a vector of random residual effects.

${ }^{3}$ Traits: $\mathrm{CE}=$ calving ease; $\mathrm{SB}=$ stillbirth; $\mathrm{GL}=$ gestation length; $\mathrm{BDEP}=$ body depth; $\mathrm{STR}=$ strength; $\mathrm{RW}=$ rump width; STAT $=$ stature. 
Table 2. Heritabilities (diagonal elements), genetic correlations (above the diagonal), and SE of genetic correlations (below the diagonal) of predictors of birth weight in the German Holstein population

\begin{tabular}{lcccccrrr}
\hline Trait $^{1}$ & BDEP & Birth weight & GL & RW & SCE & SSB & STAT & STR \\
\hline BDEP & 0.356 & 0.45 & -0.07 & 0.36 & 0.34 & 0.37 & 0.36 & 0.67 \\
Birth weight & 0.049 & 0.326 & 0.44 & 0.35 & 0.72 & 0.53 & 0.56 \\
GL & 0.061 & 0.053 & 0.472 & 0.03 & 0.34 & 0.15 & 0.08 & -0.17 \\
RW & 0.072 & 0.069 & 0.040 & 0.361 & 0.13 & 0.43 & 0.31 & 0.53 \\
SCE & 0.086 & 0.053 & 0.073 & 0.107 & 0.184 & 0.63 & 0.39 & 0.15 \\
SSB & 0.147 & 0.102 & 0.117 & 0.157 & 0.110 & 0.124 & 0.28 \\
STAT & 0.069 & 0.055 & 0.014 & 0.070 & 0.104 & 0.163 & 0.478 \\
STR & 0.049 & 0.052 & 0.057 & 0.060 & 0.105 & 0.149 & 0.066 & 0.40 \\
\hline
\end{tabular}

${ }^{1} \mathrm{BDEP}=$ body depth; GL = sire gestation length; RW = rump width; SCE = sire calving ease; SSB = sire stillbirth; STAT = stature; STR $=$ strength.

$$
\left[\begin{array}{ccc}
r_{x_{1}}^{2} \sigma_{a_{1}}^{2} & \cdots & r_{x_{1}}^{2} r_{x_{n}}^{2} \sigma_{a_{1} a_{n}} \\
\vdots & \ddots & \vdots \\
r_{x_{n}}^{2} r_{x_{1}}^{2} \sigma_{a_{n} a_{1}} & \cdots & r_{x_{n}}^{2} \sigma_{a_{n}}^{2}
\end{array}\right] \times\left[\begin{array}{c}
b_{1} \\
\vdots \\
b_{n}
\end{array}\right]=\left[\begin{array}{c}
r_{x_{1}}^{2} \sigma_{u a_{1}} \\
\vdots \\
r_{x_{n}}^{2} \sigma_{u a_{n}}
\end{array}\right]
$$

where the $r_{i}^{2}$ are the reliabilities of the predictors; the $\sigma_{i}^{2}$ and $\sigma_{i j}$ are the additive genetic variances and (co)variances of the predictors, respectively; and the $\sigma_{u i}$ are the additive genetic (co)variances of the predictors with sire birth weight. The elements of $\mathbf{b}$ are obtained in the usual manner as $\mathbf{b}=\mathbf{P}^{-1} \mathbf{G}$, and the reliability of the index is calculated as $r_{T I}^{2}=\frac{\sigma_{I}^{2}}{\sigma_{T}^{2}}$, where $\sigma_{I}^{2}=\mathbf{b}^{\prime} \mathbf{P b}$ and $\sigma_{T}^{2}=\sigma_{u}^{2}$. The relative emphasis placed on each trait was calculated by dividing each element of $\mathbf{b}$ by the sum of the elements of $\mathbf{b}$. A value of 0.445 was used for $\sigma_{u}^{2}$, based on results of B. Waurich (2011, unpublished data).

The US selection index weights were computed by inverting the left-hand side of Equation 2 and multiplying it by the right-hand side to produce a prediction of the vector $\mathbf{b}$. The phenotypic and genetic correlations (Table 2) were substituted for the German values (Table
3 ), and average reliabilities of the auxiliary traits were substituted for the $r_{i}^{2}$ in each matrix. The correlations of birth weight with the auxiliary traits were the same as used in the German data because birth weight data are not routinely available in the United States.

Genetic (co)variances and reliabilities were estimated using PTA from a subset of 3,599 Holstein bulls with reliabilities of at least $60 \%$ for all 7 predictor traits. Genetic correlations among the 4 conformation traits were obtained from the Holstein Association USA type evaluation system (T. Lawlor, Holstein Association USA, Brattleboro, VT, personal communication, 2011), and correlations among the other traits were estimated as a function of PTA correlations and their reliabilities using the method of Calo et al. (1973) as follows:

$$
\hat{r}_{g 1,2}=\frac{\sqrt{\left(\sum R L_{1}\right) \times\left(\sum R L_{2}\right)}}{\sum\left(R L_{1} \times R L_{2}\right)} \times r_{1,2},
$$

where $R L_{1}$ and $R L_{2}$ are reliabilities of traits 1 and $2, \hat{r}_{g 1,2}$ is the approximate genetic correlation between traits 1 and 2, and $r_{1,2}$ is the correlation between PTA for traits 1 and 2. The resulting genetic correlation matrix was

Table 3. Heritabilities (diagonal elements), genetic correlations (above the diagonal), and SE of genetic correlations (below the diagonal) of predictors of birth weight in the US Holstein population ${ }^{1}$

\begin{tabular}{lcccccccc}
\hline Trait $^{2}$ & BDEP & Birth weight & GL & RW & SCE & SSB & STAT & STR \\
\hline BDEP & 0.370 & 0.45 & 0.06 & 0.72 & 0.21 & 0.27 & 0.78 & 0.91 \\
Birth weight & 0.049 & 0.326 & 0.44 & 0.35 & 0.72 & 0.53 & 0.56 \\
GL & 0.013 & 0.053 & 0.138 & 0.03 & 0.03 & 0.19 & 0.04 \\
RW & N/A & 0.069 & 0.013 & 0.260 & 0.27 & 0.29 & 0.67 & 0.05 \\
SCE & 0.013 & 0.053 & 0.013 & 0.013 & 0.086 & 0.56 & 0.23 & 0.20 \\
SSB & 0.013 & 0.102 & 0.013 & 0.013 & 0.011 & 0.03 & 0.24 \\
STAT & N/A $^{3}$ & 0.055 & 0.013 & N/A & 0.013 & 0.013 & 0.420 & 0.71 \\
STR & N/A $^{3}$ & 0.052 & 0.013 & ${\text { N } / A^{3}}^{3}$ & 0.013 & 0.013 & N $^{3}$ & 0.310 \\
\hline
\end{tabular}

${ }^{1}$ Values associated with birth weight were identical to the German data because those phenotypes were not available in the United States. ${ }^{2} \mathrm{BDEP}=$ body depth; GL = sire gestation length; RW = rump width; SCE = sire calving ease; SSB = sire stillbirth; STAT = stature; and $\mathrm{STR}=$ strength

${ }^{3}$ Standard errors were not available (N/A). Genetic correlations among conformation traits were provided by Holstein Association USA (Brattleboro, VT). 
converted to a (co)variance matrix by multiplying by the appropriate additive genetic standard deviations (Table 2). Standard errors of the genetic (co)variances were estimated as follows:

$$
\mathrm{SE}=\sqrt{\frac{1-\hat{\sigma}_{g 1,2}}{n-2},}
$$

where $\hat{\sigma}_{g 1,2}$ is the genetic (co)variances among PTA for traits 1 and 2, and $n=$ the number of animals with PTA (Sokal and Rohlf, 1995).

The German and US indices were compared using both the index weights and the relative emphasis each index placed on each trait. The relative emphasis of each trait in each index was calculated by dividing the individual weights by the sum of all weights, scaling the values to a percentage, as also is done when computing the lifetime net merit index (Cole et al., 2009a).

Prediction of Birth Weight PTA. Predicted transmitting abilities for birth weight in US Holsteins were estimated using PTA for sire CE (SCE; Cole et al., 2005), sire SB (SSB; Cole et al., 2007), sire GL (Norman et al., 2009), and 4 conformation traits (Holstein Association USA, 2011): BDEP, RW, STAT, and STR. The PTA for GL were obtained in December 2012 following the procedure of Norman et al. (2009), and accuracies were calculated using the ACCF90 package (Misztal et al., 2002). Bulls were required to have PTA for all of the traits included in the index and cows were required to have pedigree indices $(\mathbf{P I})$ for all predictor traits. Pedigree indices for birth weight were constructed for cows and bulls without PTA for GL as 0.5(sire PTA $)+0.25($ maternal grandsire PTA $)+0.25($ birth year mean PTA). It also was necessary to construct PI of SCE and SSB for cows because those PTA are computed using a sire-maternal grandsire model that does not provide cow PTA. The final data set of birth weight pseudo-phenotypes included predicted birth weight PTA and reliabilities for 290,210 Holstein animals, including 31,948 bulls with PTA for all traits in the index, 159,947 bulls with PI for birth weight, and 98,317 cows with PI for birth weight, and the pedigree file included 722,662 records. Deregressed PTA were computed by dividing the PTA by the squared reliability (Garrick et al., 2009) and used as phenotypes for subsequent genome-wide association studies.

\section{Genome-Wide Association Study}

The genomic data set included 258,262 animals with PTA or PI for birth weight, calculated as described in the previous section (159,945 bulls and 98,317 cows) with available genotypes. Of those, 53,644 (19,792 bulls and 33,852 cows) constituted the discovery population used for the prediction of SNP effects, and the remaining 204,618 (51,934 bulls and 152,684 cows) were the validation set. The data set included BovineSNP50 BeadChip (Illumina Inc., San Diego, CA) genotypes (mostly bulls), as well as low-density genotypes (predominantly cows) imputed to the BovineSNP50 BeadChip SNP set using version 2 of the findhap program (VanRaden et al., 2011a). Allele substitution effects for the 45,188 SNP used in the December 2012 US genetic evaluations were estimated using an infinitesimal alleles model with a heavy-tailed prior in which smaller effects are regressed further toward 0 and markers with larger effects are regressed less to account for a nonnormal distribution of marker effects (VanRaden, 2008; VanRaden et al., 2011b). Marker effects were randomly distributed with a heavy-tailed distribution generated by dividing a normal variable by $h^{|s|-2}$, where $h$ determines departure from normality and $s$ is the size of the estimated marker effect in standard deviations (VanRaden, 2008). When $h$ is 1 , marker effects are normally distributed with no additional weight in the tails, and variance in the tails grows with increasing values of $h$. A value for $h$ of 1.2, which is used for routine genomic evaluations in US Holsteins, also was used in this study.

Gene annotation information is based on the National Center for Biotechnology Information (NCBI) build 6.1 (http://www.ncbi.nlm.nih.gov/assembly/313728/) of the bovine genome. Coordinates are based on the UMD 3.1 version of the Bos taurus genome assembly (Zimin et al., 2009). Manhattan plots were created using ggplot2 0.9.2 (Wickham, 2009) and R 2.15.1 (R Development Core Team, 2010) systems on an IBM xSeries 3850 server (IBM Corp., Armonk, NY) running Red Hat Enterprise Linux 5.0 (Red Hat Inc., Raleigh, $\mathrm{NC})$.

\section{Validation of Chromosome 18 Effects}

Previous studies have reported the presence of a QTL on chromosome 18. Generalized (GLM) and mixed linear models (MLM), as implemented in TASSEL 3.0.163 software (Bradbury et al., 2007), were used to perform single-SNP analyses for the markers located on chromosome 18 to determine if different analyses rank the SNP similarly. The models used for the GLM and MLM were as follows:

$$
\begin{gathered}
\text { GLM: } \mathbf{y}=\mathbf{X} \boldsymbol{\beta}+\mathbf{e} \\
\text { MLM: } \mathbf{y}=\mathbf{X} \boldsymbol{\beta}+\mathbf{Z u}+\mathbf{e},
\end{gathered}
$$

where $\mathbf{y}$ is a vector of deregressed PTA for birth weight, $\boldsymbol{\beta}$ is an unknown vector of fixed SNP effects, $\mathbf{u}$ is a 
vector of unknown random additive genetic effects from background QTL, $\mathbf{X}$ and $\mathbf{Z}$ are known design matrices, and $\mathbf{e}$ is a vector of random error terms. The elements of $\mathbf{u}$ are normally distributed, with a mean of 0 and a variance of $\mathbf{K} \sigma_{a}^{2}$, where $\mathbf{K}$ is a SNP-based kinship matrix and $\sigma_{a}^{2}$ is the additive genetic variance of birth weight. Error terms are normally distributed with a mean of 0 and a variance of $\mathbf{I} \sigma_{e}^{2}$, where $\mathbf{I}$ is an identity matrix and $\sigma_{e}^{2}$ is the residual (error) variance. A principal components analysis was used to assess the degree of stratification present in the population.

\section{Pathway Analysis}

The 100 SNP with the largest allele substitution effects for birth weight were chosen for further analysis. Individual SNP were associated with the closest, annotated gene using the BEDTools package closestBed program (Quinlan et al., 2009). The Database for Annotation, Visualization and Integrated Discovery (DAVID; Dennis et al., 2003) 6.7 was used to conduct a gene-set enrichment analysis for birth weight (Huang et al., 2009). Gene-set enrichment analysis is used to identify gene pathways that contain large numbers of genes with large effects for the phenotype of interest. The Weizmann Institute GeneALaCart web tool (http:// www.genecards.org/BatchQueries/index.php) was used to identify associated pathways for each gene as well as to query the literature for gene functions. Data tracks from the University of California, Santa Cruz (UCSC) Genome Browser (Kent et al., 2002) were used to identify regions of cross-species sequence homology.

\section{RESULTS AND DISCUSSION}

\section{Selection Indices for the Prediction of Birth Weight}

Index weights and the relative emphasis on each trait for the German and US indices are presented in Table
4. Four traits in each index have relatively large coefficients relative to the other 3 . In both indices, SCE and SSB receive more than $40 \%$ of the emphasis, with 46.5 and $40.4 \%$ in Germany and the United States, respectively. The indices differ somewhat in that BDEP and STR are the other heavily weighted traits in the German index, whereas GL and STAT have large coefficients in the US index. The genetic correlation of GL with SCE is much larger in the German population than the United States, which may explain why less emphasis is placed on SCE in the US index (20.0 vs. $30.6 \%$ ), and why much more emphasis is placed on GL in the US index (33.5 vs. $6.1 \%$ ). The genetic correlations for BDEP and STR also differ substantially between the German and US indices, with differences of 13 and $22 \%$, respectively. The differences in the genetic correlation structure are expected to affect the resulting PTA for birth weight, and rank (Spearman) correlations among correlations calculated using the US and German weights with the US PTA were only 0.77.

In the US index, $32.8 \%$ of the relative emphasis is on SCE and STAT. Stature is defined as the height at the hips of a cow, with an average cow standing 143.5 $\mathrm{cm}$ (56.6 in) tall, and SCE is the percentage of difficult births expected among calves sired by a particular bull. A negative association between dystocia and conformation has been described several times in the literature (e.g., Thompson et al., 1980; Dadati et al., 1985). Ali et al. (1984) did find favorable associations among some physical measurements of daughters and their calving ease, but that reflects daughter calving ease rather than SCE. McDermott et al. (1992) found that birth weight is the most important predictor of dystocia, so it is not surprising that dystocia is an important predictor of calf birth weight. Moderate genetic correlations of GL with CE were reported by Jamrozik et al. (2005). Hansen et al. (2004) found a modest genetic correlation of SCE with GL $(+0.18)$, a larger correlation between GL and birth weight $(+0.38)$, and an extremely strong

Table 4. Selection index coefficients and relative emphasis on predictors of birth weight for the German and US Holstein populations

\begin{tabular}{|c|c|c|c|c|}
\hline \multirow[b]{2}{*}{ Trait $^{1}$} & \multicolumn{2}{|c|}{ Germany } & \multicolumn{2}{|c|}{ United States } \\
\hline & Coefficient & Emphasis (\%) & Coefficient & Emphasis (\%) \\
\hline BDEP & 0.6849 & 15.2 & 0.1168 & 7.2 \\
\hline GL & 0.2766 & 6.1 & 0.5456 & 33.5 \\
\hline RW & 0.4303 & 9.5 & 0.0301 & 1.8 \\
\hline SCE & 1.3808 & 30.6 & 0.3250 & 20.0 \\
\hline SSB & 0.7182 & 15.9 & 0.3292 & 20.2 \\
\hline STAT & 0.3731 & 8.3 & 0.2089 & 12.8 \\
\hline STR & 0.6544 & 14.5 & 0.0690 & 4.2 \\
\hline
\end{tabular}

${ }^{1}$ The traits included in each index were body depth (BDEP), sire gestation length (GL), rump width (RW), sire calving ease (SCE), sire stillbirth (SSB), stature (STAT), and strength (STR). 
correlation of SCE with birth weight $(+0.93)$, although they concluded that the association of GL with birth weight was weak. The relatively low emphasis on GL in the German index of $6.1 \%$ is consistent with such a finding. One explanation for the heavy emphasis on GL in the US index may be the segregation of a QTL associated with GL (Maltecca et al., 2009), but that QTL also is segregating in the German Holstein population (Brand et al., 2010). Boldman and Famula (1985) reported that extensive use of good-CE bulls could produce progeny with lower scores for several conformation traits, including STAT and RW. Cue et al. (1990) reported unfavorable genetic correlations of SCE with capacity (similar to strength) and RW in heifers, and with capacity in mature cows.

\section{Predicted Birth Weight in US Holsteins}

PTA and Reliabilities. Summary statistics for PTA and reliabilities of birth weight are presented in Table 5 for 2 groups of animals: bulls with selection index-based predictions of birth weight, and animals with PTA computed using PI. Properties of the PTA were similar for the 2 groups, but the average reliabilities were much lower for the animals with PI. The distributions of birth weight PTA and reliabilities for the 31,948 bulls with selection index-based PTA are shown in Figures 1 and 2, respectively. The reliabilities in Figure 2 were calculated using the selection index as described above. There were 2,324 bulls with reliabilities of at least $90 \%$, and they all were older bulls born between 1956 and 1991 that had high reliabilities for the traits in the selection index. It appears that reliabilities for older bulls may have been overestimated, possibly as a result of the approximation used to compute the reliabilities of CE and SB (Van Tassell et al., 2003).

The 10 bulls with the smallest and largest PTA for birth weight are shown in Table 6. Eight of the bulls sired fewer than 100 daughters with lactation records, whereas 7 had more than 1,000 milking daughters. The Holstein bull Round Oak Rag Apple Elevation (HOUSA000001491007) was the source of the QTL reported by Cole et al. (2009b), and he appeared as the maternal grandsire of both low- and high-birth-weight PTA bulls.

Correlation of Birth Weight with Traits Not in the Index. Correlations of birth weight PTA with PTA for several traits not in the index were used to approximate genetic correlations. All correlations were different from $0(P<0.05)$. Milk, fat, and protein yield had small, negative correlations of $-0.02,-0.01$, and -0.02 with birth weight, respectively. These results are consistent with those of Legault and Touchberry (1962), who reported negative, nonsignificant correla-

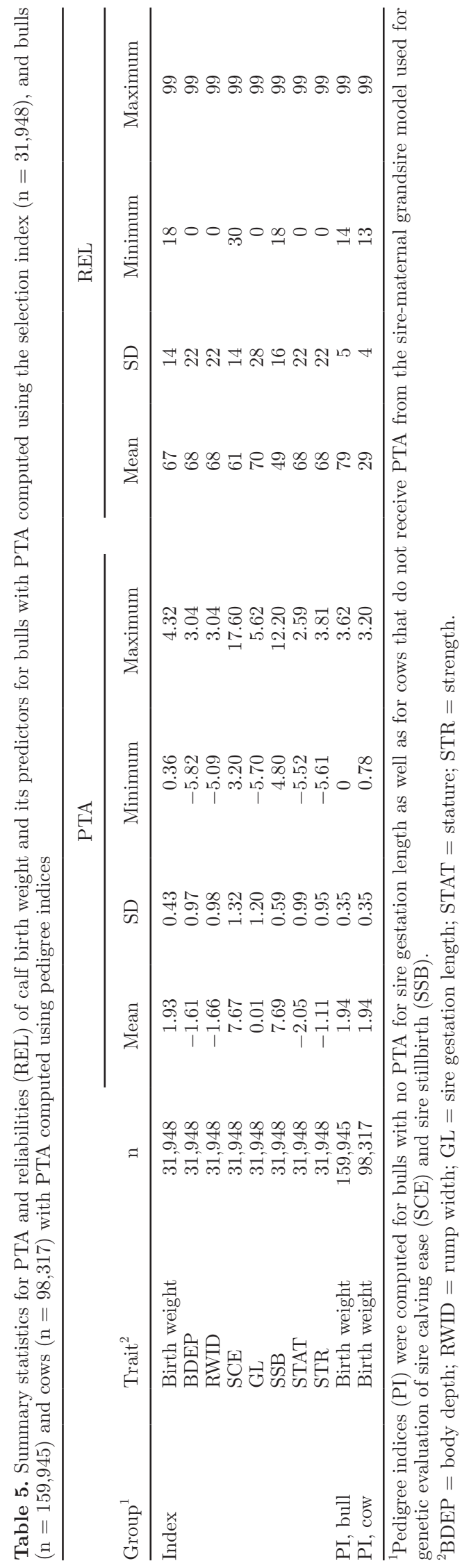




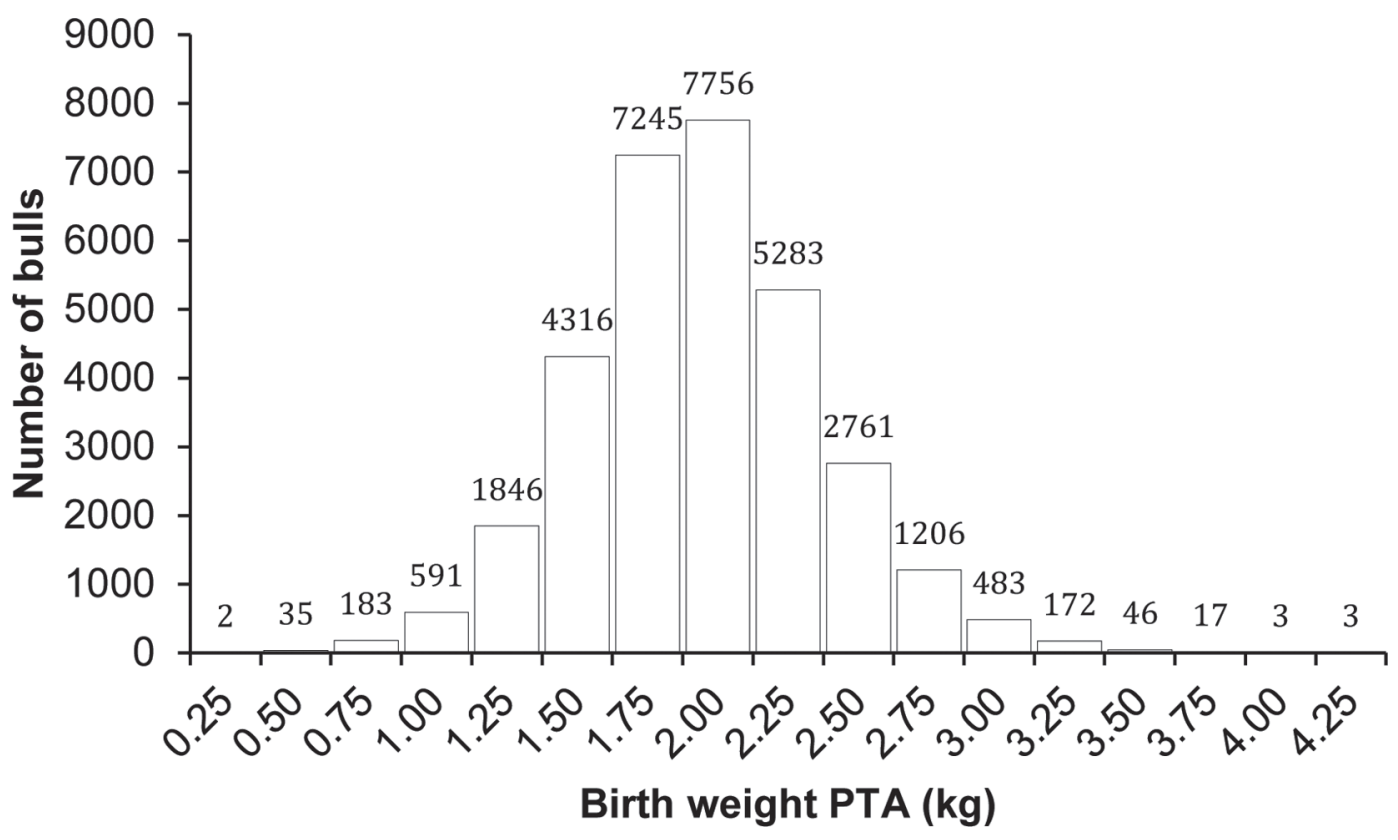

Figure 1. Distribution of sire predicted transmitting abilities for calf birth weight for the 31,948 bulls with PTA for the birth weight predictor traits (body depth, rump width, sire calving ease, sire gestation length, sire stillbirth, stature, and strength).

tions of birth weight with dam milk and fat yield. Swali and Wathes (2006) reported no significant phenotypic association of birth weight with milk yield, but Chew et al. (1981) found a positive association of the 2 traits.

Correlations of birth weight PTA with fitness traits were -0.06 for daughter pregnancy rate (a measure of fertility; VanRaden et al., 2004), -0.09 for lifetime net merit (a measure of profitability; Cole et al., 2009a), 0.09 for productive life (a measure of longevity; VanRaden and Wiggans, 1995), and +0.04 for SCS (a measure of udder health; Schutz, 1994). These correlations all are unfavorable. Dystocia, which is strongly associated with birth weight, has adverse effects on several measures of fertility in the dairy cow (e.g., Meijering,

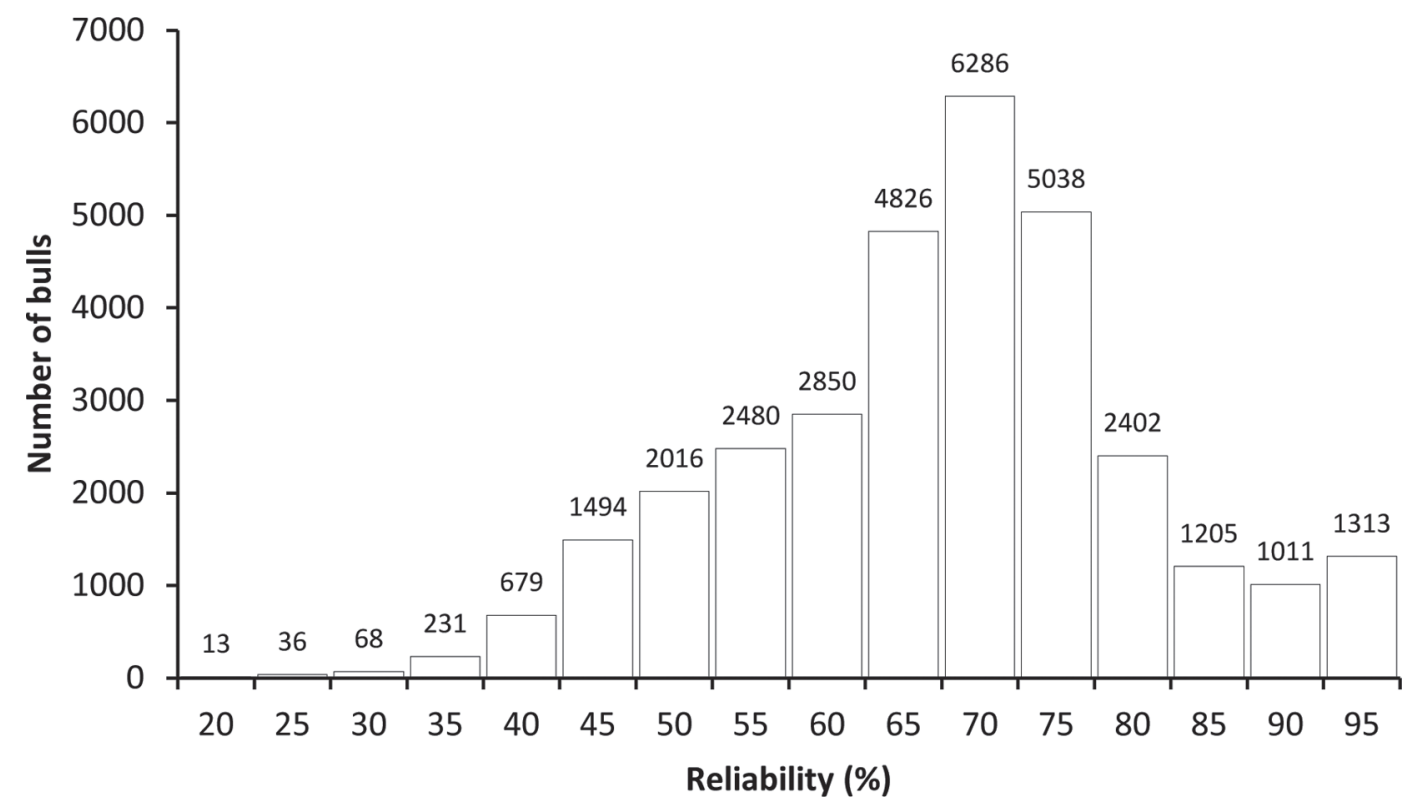

Figure 2. Distribution of the approximate reliability (\%) of PTA for calf birth weight for the 31,948 bulls with PTA for the birth weight predictor traits (body depth, rump width, sire calving ease, sire gestation length, sire stillbirth, stature, and strength). 
COLE ET AL.

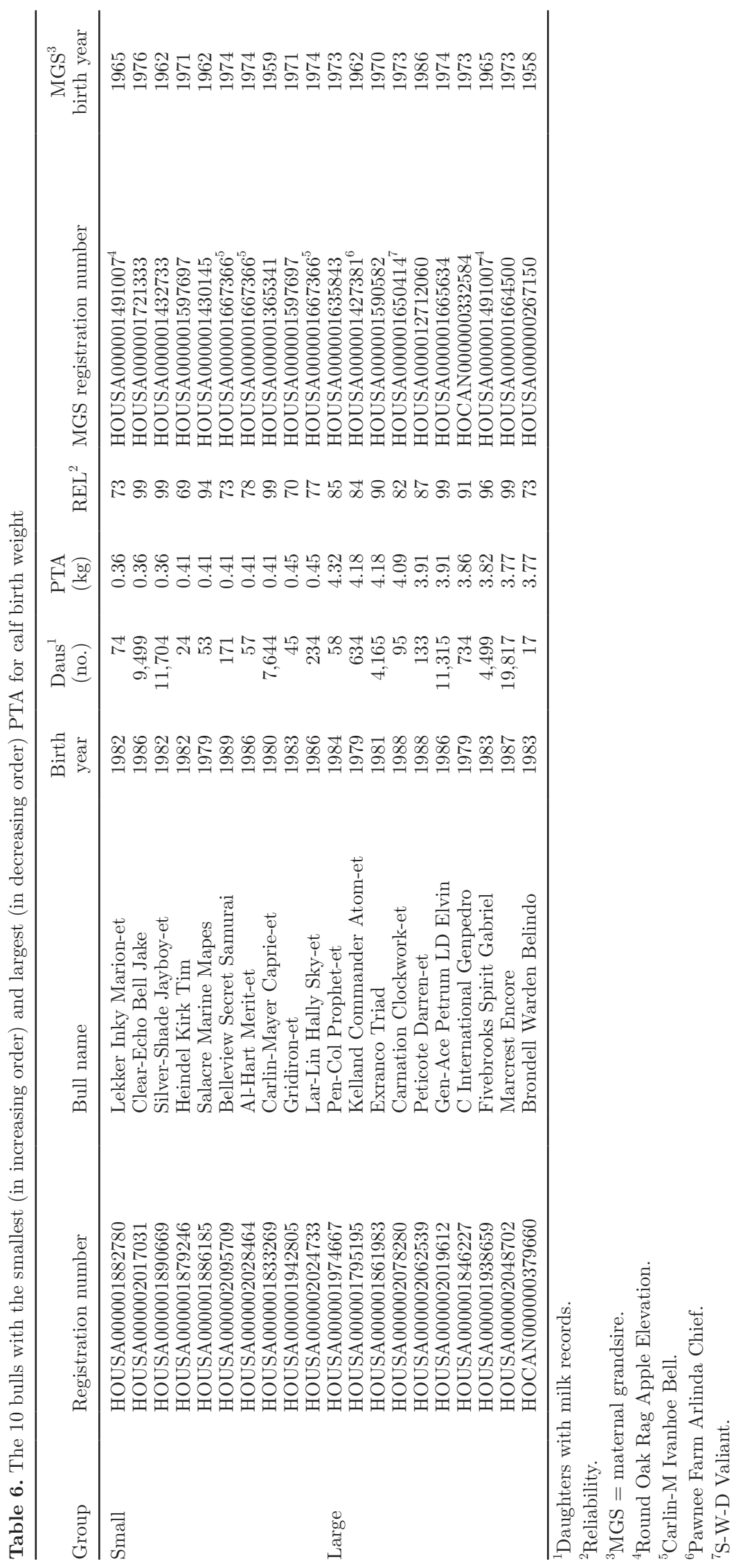




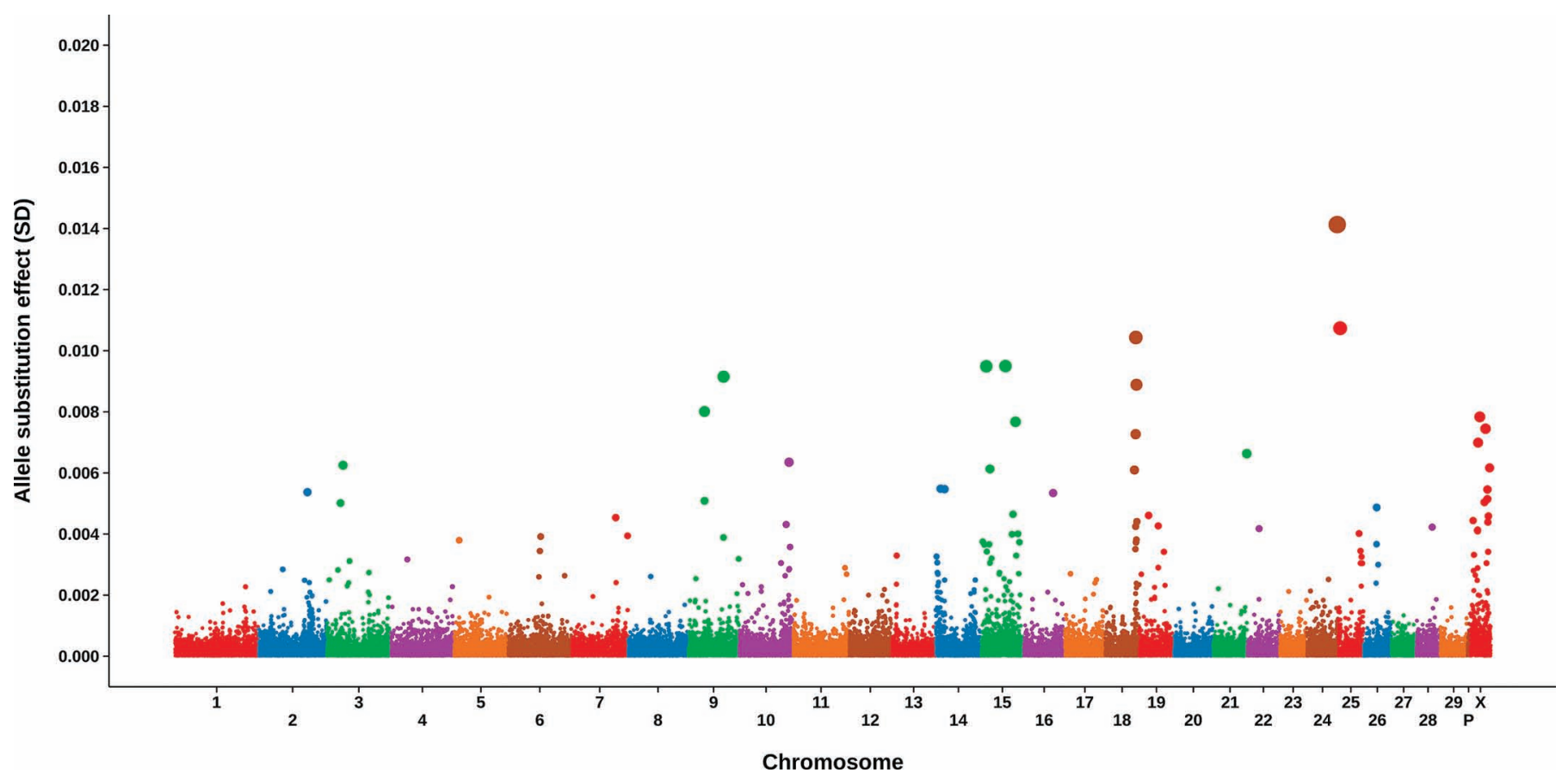

Figure 3. Size of marker effects in additive genetic SD for predicted birth weight. Point areas are proportional to marker effects. Color version available in the online PDF.

1984). Berry et al. (2007) also reported that dystocia is associated with increased SCS in early lactation. These correlations seem reasonable in light of the association of birth weight with dystocia, and the association of dystocia with these fitness traits.

The PTA correlations of birth weight with conformation traits not included in the index ranged from -0.045 (rump angle) to +0.21 (final score). All correlations except for rump angle were positive. These results suggest that bulls that sire large calves also produce daughters with greater-than-average conformation scores, which is generally consistent with previous reports (e.g., Thompson et al., 1980; Ali et al., 1984; Dadati et al., 1985; Koenen and Groen, 1996; Coffey et al., 2006).

\section{Analysis of Genomic Data}

Genome-Wide Association Study. Allele substitution effects scaled to units of additive genetic standard deviations are shown in Figure 3, and the name, location, effect size, and functional information for the 25 SNP with the largest effects on birth weight are shown in Table 7 . This includes individual SNP on chromosomes $2,3,9,10,14,15,16,21,24$, and 25 , as well as groups of SNP in close proximity to one another on chromosomes 18 and 31. Twelve SNP are intragenic, 9 are located near $(\leq 100 \mathrm{~kb})$ genes, and 4 are not located near any annotated genes $(>100 \mathrm{~kb})$.
The largest marker effect among the top 25 is 0.014 standard deviation, and the smallest is 0.005 standard deviation.

Several factors may affect the power of the association study. The rank correlation of German birth weight PTA with the PTA predicted using the German correlation matrices in the selection index was +0.78 for bulls with a minimum reliability of 0.40 . This suggests that factors exist affecting birth weight that are not accounted for in the index, which could result in decreased power to detect genomic regions affecting birth weight.

The method used to deregress the PTA and PI does not account for the sources of information that contribute to the reliability (e.g., individual's own phenotype, progeny records, or parental performance). This may be problematic when, as in the current study, PI are computed and deregressed for many animals. The statistical power of the analysis may be overstated and the false discovery rate higher than expected, as a result.

Validation of Chromosome 18 SNP Effects. A disadvantage of the genomic BLUP (gBLUP) methodology used in this study is that marker effects can be distributed among SNP that are in high linkage disequilibrium (LD) with one another, which can make QTL difficult to detect or locate accurately. Although putative QTL identified in the US population have been confirmed in studies using different methodologies (e.g., 


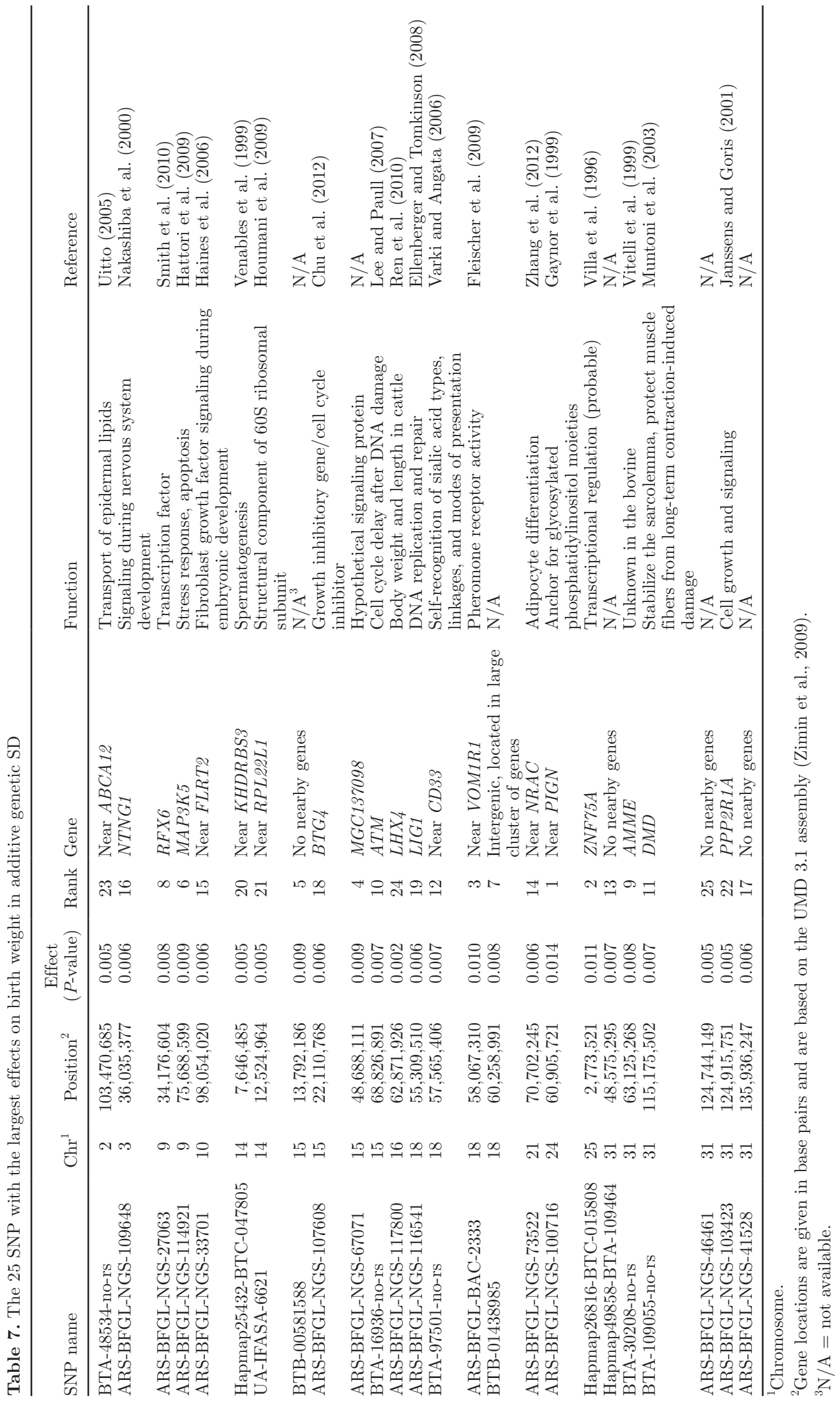


Cole et al., 2009b, 2011), the change in location of the QTL on BTA 18 was surprising. The GLM and MLM analyses were conducted to determine if the change in location represents a true biological effect, or if it is an artifact of the analysis used.

A 50-SNP sliding-window analysis of LD in TASSEL showed that the original QTL (ARS-BFGL-NGS-109285 at $57,589,121 \mathrm{bp}$ ) is in close linkage with the gBLUP QTL (ARS-BFGL-BAC-2333 at 58,067,310 bp) in the same region $\left(\mathrm{r}^{2}=0.38 ; P<0.0001\right)$. Results of the principal components analysis showed no significant stratification among the animals used in this study. The original QTL had the third-highest significance $\left(-\log _{10} P=9.49\right)$ of all markers on BTA18 in the GLM (Supplemental Figure S1; http://dx.doi.org/10.3168/ jds.2013-7409), and was the most significant SNP in the MLM $\left(-\log _{10} P=5.50\right.$; Supplemental Figure S2). These results suggest that the SNP associated with the true QTL is ARS-BFGL-NGS-109285, as originally reported by Cole et al. (2009b), and not ARS-BFGL-BAC-2333.

Future association studies should use methods such as the unified mixed-model approach of Yu et al. (2006) for fine-mapping QTL, rather than gBLUP, to more accurately identify true QTL when many markers are in tight $\mathrm{LD}$ with one another. In cases where computational limitations may preclude such an approach, gBLUP could be used to identify chromosomal regions of interest, and an MLM approach could be used on subsets of markers in interesting regions.

One notable limitation of the association analyses conducted in this study is that the birth weight predictor used can identify only QTL associated with the traits in the predictor. If a QTL is associated with birth weight, but not the predictors in the selection index, then it will not be identified using these methods unless such associations are found by chance. This means that the following discussion of genes and pathways associated with birth weight is necessarily incomplete. This problem cannot be overcome with statistical methodology, and must be addressed by the routine recording of birth weight phenotypes in the United States.

Genes Associated with Large Effects. The function of genes associated with large SNP effects can be loosely grouped into 2 categories: those involved in growth and development, and those associated with other processes, such as the cell cycle and signaling. The former include ABCA12, FLRT2, LHX4, MAP3K5, NRAC, NTNG1, and PIGN, whereas the latter include $A T M, B T G, C D 33$, and LIH1. In the following discussion, each gene has been placed into 1 of these 2 groups. Table 7 includes detailed information about the 25 SNP with the largest effects (in additive genetic SD) on birth weight, including position (mbp), gene name and function, and references to relevant literature.
Genes Associated with Growth and Development. The SNP with the largest effect was ARSBFGL-NGS-100716 (rs110729775) at 60,905,721 bp on BTA24. This marker is $72 \mathrm{kbp}$ upstream of the PIGN gene, which encodes a protein that is crucial in the manufacture of anchors for glycosylated phosphatidylinositol moieties (Gaynor, et al. 1999). Lossof-function mutations of PIGN have been linked to neonatal hypotonia in humans (Maydan et al., 2011) and chromosome instability in dividing cells (Burrell et al., 2013). Although the downstream effects of modified glycosylphosphatidylinositol molecules produced by PIGN proteins are still unclear, the results of several studies indicate that the gene's activity may be important in development.

Several regions on BTA14 have been associated with increased birth weight, although some studies report microsatellite coordinates in centimorgans $(\mathrm{cM})$, rather than SNP locations in base pairs, making comparisons difficult. In the current study, 2 SNP on BTA14 had large effects, one near KHDRBS3, which is involved in spermatogenesis (Venables et al., 1999), and the second near RPL22L1, a ribosomal subunit (Houmani et al., 2009). These results differ from earlier studies that reported effects on birth weight on BTA14 (Davis et al., 1998; Kneeland et al., 2004; Koshkoih et al., 2006; Maltecca et al., 2008; Pausch et al., 2011), possibly because of differences among the populations studied.

A SNP on BTA15, BTB-00581588 (rs41745294) at $13,792,186 \mathrm{bp}$, was originally believed to be in a gene desert. Closer investigation revealed that this SNP is located in a region that has high percentage similarity with a human sequenced RNA molecule extracted from placental tissue (MGC accession: BC033698; http://www.ncbi.nlm.nih.gov/nuccore/BC033698). To our knowledge, the function of this highly conserved, putatively transcribed region of the genome has not yet been investigated and may serve as an excellent starting point in future studies on mother-offspring developmental signaling pathways.

The SNP ARS-BFGL-NGS-117800 (rs110406930) at $62,871,926$ bp on BTA16 is intronic to $L H X_{4}$, which is related to body weight and body length in Chinese cattle (Ren et al., 2010). Mutations in $\mathrm{LHX}_{4}$ have been associated with pituitary hormone deficiencies in humans (Pfaeffle et al., 2008), suggesting that it is necessary for proper development of the hypothalamicpituitary axis.

Several other SNP were associated with genes that may be involved with growth and development, but the links are somewhat tenuous: ZNF75A may be upregulated in bovine embryos (Smith et al., 2009); $A B C A 12$ is involved in the transport of epithelial lipids (Uitto, 2005) and ichthyosis fetalis in Chianina cattle (Charlier 
et al., 2008); NTNG1 is involved in cell signaling during nervous system development (Nakashiba et al., 2000), and mutations in NTNG1 are associated with developmental disorders in humans (Lin et al., 2009); RFX6 is essential for pancreatic islet cell formation (Smith et al., 2010); MAP3K5 is associated with developmental competency of bovine embryos (Pfeffer et al., 2007); and FLRT2 is associated with fibroblast growth factor signaling during embryonic development, heart morphogenesis, and embryonic survival (Haines et al., 2006; Müller et al., 2011). The NRAC gene is highly expressed in murine adipose and heart tissue (Zhang et al., 2012), and adipose tissue development occurs during mid to late gestation in the cow (Du et al., 2011). Genes of note on the $\mathrm{X}$ chromosome include $A M M E$, linked to Alport syndrome, midface hypoplasia, and elliptocytosis in humans (Vitelli et al., 1999); DMD, a gene involved in muscle development (Muntoni et al., 2003); and PP2R1A, which affects cell growth and signaling (Janssens and Goris, 2001).

Height receives $14.7 \%$ of the emphasis in the birth weight predictor in the form of STAT (Table 4), so it would not have been surprising if 1 or more heightrelated genes had large effects. Several genes associated with human height have homologs in the cow (Pausch et al., 2011; Pryce et al., 2011; Utsunomiya et al., 2013), but none of those genes were identified as having large effects on birth weight. It is not surprising that different genes may be associated with mature height and birth weight, although Horikoshi et al. (2013) have reported on associations of intrauterine growth with adult height in humans.

Genes Associated with Other Cellular Processes. A group of 4 markers spanned a region of BTA18 from $55,309,510$ to $60,258,991 \mathrm{bp}$. The SNP with the largest effect is located near VOM1R1, which is associated with pheromone receptor activity (Fleischer et al., 2009). Other genes located close to large SNP include CD33 (Simmons and Seed, 1988; Varki and Angata, 2006) and LIG1 (DNA replication and repair; Ellenberger and Tomkinson, 2008). This is a generich region that was previously identified by Cole at al. (2009b) as containing a QTL affecting calving and conformation traits in US Holsteins, as well a QTL for direct (sire) gestation length by Maltecca et al. (2011). Several structural variations have been found in this region, including insertion, deletions, and copy number variants (Hou et al., 2011). These structural variants may represent a high degree of paralogous gene families in this region of the chromosome, which are notoriously difficult to assemble (Eichler, 1998).

Gene Networks Associated with Birth Weight. The analysis of genes associated with SNP with large effects on birth weight identified the "regulation of actin cytoskeleton" pathway (bta04810) as enriched compared with other pathways. Several genes in this pathway are associated with embryonic development and cell growth, including focal adhesion kinase (FAK; Corsi et al., 2006), p21-activated kinases (PAK; Hofmann et al., 2004), and Rho-associated protein kinases (ROCK; Wei et al., 2001). Increased expression of the $R O C K 2$ isoform may be a mediator of placental apoptosis, and it is associated with preeclampsia in humans (Ark et al., 2005). The bovine placenta is cotyledonous rather than hemochorionic as in humans, but ROCK also may play a role in placental support of the fetus in the cow.

\section{CONCLUSIONS}

Prediction equations derived from one population may be useful for identifying genes and gene networks associated with phenotypes that are not directly measured in a second population. The differences among birth weight PTA estimated using the German and US index weights suggest that the prediction equations require additional refinement before they are suitable for routine evaluation, but the results of the genome-wide association study suggest that the resulting PTA are useful for identifying SNP associated with growth and development. These results also show that the classical framework of quantitative genetics in animal breeding (e.g., selection index theory and estimation of variance components using restricted maximum likelihood) can be used for modern analyses, in this case a genomewide association study based on high-throughput SNP genotyping of many animals.

\section{ACKNOWLEDGMENTS}

The cooperation of the American Jersey Cattle Association (Reynoldsville, $\mathrm{OH}$ ), Brown Swiss Association (Beloit, WI), and Holstein Association USA (Brattleboro, VT) in supplying pedigree data for registered cows and the dairy records processing centers [AgriTech Analytics (Visalia, CA), AgSource Cooperative Services (Verona, WI), Dairy Records Management Systems (Raleigh, NC, and Ames, IA), and DHI Computing Services (Provo, UT)] in supplying pedigree data for grade cows and calving event data is acknowledged. The National Association of Animal Breeders (Columbia, MO) contributed to funding the national calving traits evaluations. Holstein Association USA provided the US conformation evaluations used in this study. D. M. Bickhart and J. B. Cole were supported by the USDA Agricultural Research Service appropriated project 1245-31000-101-00, "Improving Genetic Predictions in Dairy Animals Using Phenotypic and Genomic 
Information." Two anonymous reviewers are thanked for their comments and suggestions, which improved the quality of the manuscript.

\section{REFERENCES}

AIPL (Animal Improvement Programs Laboratory). 2013. Trait evaluations: Calving (calving ease, stillbirth). Accessed Jan. 17, 2013. http://aipl.arsusda.gov/reference/Form_GE_CT_1008.pdf.

Ali, T. E., E. B. Burnside, and L. R. Schaeffer. 1984. Relationship between external body measurements and calving difficulties in Canadian Holstein-Friesian cattle. J. Dairy Sci. 67:3034-3044.

Ark, M., N. Yılmaz, G. Yazıcı, H. Kubat, and S. Aktaş. 2005. Rhoassociated protein kinase II (rock II) expression in normal and preeclamptic human placentas. Placenta 26:81-84. http://dx.doi. org/10.1016/j.placenta.2004.03.012.

Berry, D. P., J. M. Lee, K. A. Macdonald, and J. R. Roche. 2007. Body condition score and body weight effects on dystocia and stillbirths and consequent effects on postcalving performance. J. Dairy Sci. 90:4201-4211.

Boldman, K. G., and T. R. Famula. 1985. Association of sire dystocia transmitting ability with progeny linear type traits in Holsteins. J. Dairy Sci. 68:2052-2057.

Bradbury, P. J., Z. Zhang, D. E. Kroon, T. M. Casstevens, Y. Ramdoss, and E. S. Buckler. 2007. TASSEL: Software for association mapping of complex traits in diverse samples. Bioinformatics 23:2633-2635.

Brand, B., C. Baes, M. Mayer, N. Reinsch, T. Seidenspinner, G. Thaller, and C. Kühn. 2010. Quantitative trait loci mapping of calving and conformation traits on Bos taurus autosome 18 in the German Holstein population. J. Dairy Sci. 93:1205-1215.

Burrell, R. A., S. E. McClelland, D. Endesfelder, P. Groth, M.-C. Weller, N. Shaikh, E. Domingo, N. Kanu, S. M. Dewhurst, E. Gronroos, S. K. Chew, A. J. Rowan, A. Schenk, M. Sheffer, M. Howell, M. Kschischo, A. Behrens, T. Helleday, J. Bartek, I. P. Tomlinson, and C. Swanton. 2013. Replication stress links structural and numerical cancer chromosomal instability. Nature 494:492-496. http://dx.doi.org/10.1038/nature11935.

Calo, L. L., R. E. McDowell, L. D. VanVleck, and P. D. Miller. 1973. Genetic aspects of beef production among Holstein-Friesians pedigree selected for milk production. J. Anim. Sci. 37:676-682.

Cameron, N. D. 1997. Selection Indices and Prediction of Genetic Merit in Animal Breeding. CAB International, New York, NY.

Charlier, C., W. Coppieters, F. Rollin, D. Desmecht, J. S. Agerholm, N. Cambisano, E. Carta, S. Dardano, M. Dive, C. Fasquelle, J.C. Frennet, R. Hanset, X. Hubin, C. Jorgensen, L. Karim, M. Kent, K. Harvey, B. R. Pearce, P. Simon, N. Tama, H. Nie, S. Vandeputte, S. Lien, M. Longeri, M. Fredholm, R. J. Harvey, and M. Georges. 2008. Highly effective SNP-based association mapping and management of recessive defects in livestock. Nat. Genet. 40:449-454. http://dx.doi.org/10.1038/ng.96.

Chew, B. P., L. C. Maier, J. K. Hillers, and A. S. Hodgson. 1981. Relationship between calf birth weight and dam's subsequent 200- and 305-day yields of milk, fat, and total solids in Holsteins. J. Dairy Sci. 64:2401-2408.

Chu, T., I. Dufort, and M.-A. Sirard. 2012. Effect of ovarian stimulation on oocyte gene expression in cattle. Theriogenology 77:19281938.

Coffey, M. P., J. Hickey, and S. Brotherstone. 2006. Genetic aspects of growth of Holstein-Friesian dairy cows from birth to maturity. J. Dairy Sci. 89:322-329.

Cole, J. B., R. C. Goodling Jr., G. R. Wiggans, and P. M. VanRaden. 2005. Genetic evaluation of calving ease for Brown Swiss, Jersey, and Holstein bulls from purebred and crossbred calvings. J. Dairy Sci. 88:1529-1539.

Cole, J. B., P. M. VanRaden, and Multi-State Project S-1040. 2009a. Net merit as a measure of lifetime profit: 2010 revision. AIPL Research Report NM\$4. Accessed Jan. 18, 2013. http://aipl.arsusda. gov/reference/nmcalc.htm.
Cole, J. B., P. M. VanRaden, J. R. O'Connell, C. P. Van Tassell, T. S. Sonstegard, R. D. Schnabel, J. F. Taylor, and G. R. Wiggans. 2009b. Distribution and location of genetic effects for dairy traits. J. Dairy Sci. 92:2931-2946.

Cole, J. B., G. R. Wiggans, L. Ma, T. S. Sonstegard, T. J. Lawlor, B. A. Crooker, C. P. Van Tassell, J. Yang, S. Wang, L. K. Matukumalli, and Y. Da. 2011. Genome-wide association analysis of thirty one production, health, reproduction and body conformation traits in contemporary U.S. Holstein cows. BMC Genomics 12:408. http://dx.doi.org/10.1186/1471-2164-12-408.

Cole, J. B., G. R. Wiggans, and P. M. VanRaden. 2007. Genetic evaluation of stillbirth in United States Holsteins using a sire-maternal grandsire threshold model. J. Dairy Sci. 90:2480-2488.

Corsi, J.-M., E. Rouer, J.-A. Girault, and H. Enslen. 2006. Organization and post-transcriptional processing of focal adhesion kinase gene. BMC Genomics 7:198 http://dx.doi.org/10.1186/14712164-7-198.

Cue, R. I., H. G. Monardes, and J. F. Hayes. 1990. Relationships of calving ease with type traits. J. Dairy Sci. 73:3586-3590.

Dadati, E., B. W. Kennedy, and E. B. Burnside. 1985. Relationships between conformation and reproduction in Holstein cows: Type and calving performance. J. Dairy Sci. 68:2639-2645.

Davis, G. P., D. J. S. Hetzel, N. J. Corbet, S. Scacheri, S. Lowden, J. Renaud, C. Mayne, R. Stevenson, S. S. Moore, and K. Byrne. 1998. The mapping of quantitative trait loci for birth weight in tropical beef herd. Pages 441-444 in Proc. 6th World Congr. Genet. Appl. Livest. Prod., Armidale, NSW, Australia.

Dennis, G. Jr., B. T. Sherman, D. A. Hosack, J. Yang, W. Gao, H. C. Lane, and R. A. Lempicki. 2003. DAVID: Database for annotation, visualization, and integrated discovery. Genome Biol. 4:P3.

Du, M., J. X. Zhao, X. Yan, Y. Huang, L. V. Nicodemus, W. Yue, R. J. McCormick, and M. J. Zhu. 2011. Fetal muscle development, mesenchymal multipotent cell differentiation, and associated signaling pathways. J. Anim. Sci. 89:583-590. http://dx.doi.org/10.2527/ jas.2010-3386.

Eaglen, S. A. E., M. P. Coffey, J. A. Woolliams, and E. Wall. 2012. Evaluating alternate models to estimate genetic parameters of calving traits in United Kingdom Holstein Friesian dairy cattle. Genet. Sel. Evol. 44:23.

Eberlein, A., A. Takasuga, K. Setoguchi, R. Pfuhl, K. Flisikowski, R. Fries, N. Klopp, R. Fürbass, R. Weikard, and C. Kühn. 2009. Dissection of genetic factors modulating fetal growth in cattle indicates a substantial role of the non-SMC condensin I complex, subunit G (NCAPG) gene. Genetics 183:951-964.

Eichler, E. E. 1998. Masquerading repeats: Paralogous pitfalls of the human genome. Genome Res. 8:758-762.

Ellenberger, T., and A. E. Tomkinson. 2008. Eukaryotic DNA ligases: Structural and functional insights. Annu. Rev. Biochem. 77:313338.

Fleischer, J., H. Breer, and J. Strotmann. 2009. Mammalian olfactory receptors. Front. Cell. Neurosci. 3:9 http://dx.doi.org/10.3389/ neuro.03.009.2009.

Garrick, D. J., J. F. Taylor, and R. L. Fernando. 2009. Deregressing estimated breeding values and weighting information for genomic regression analyses. Genet. Sel. Evol. 41:55 http://dx.doi. org/10.1186/1297-9686-41-55.

Gaynor, E. C., G. Mondésert, S. J. Grimme, S. I. Reed, P. Orlean, and S. D. Emr. 1999. MCD4 encodes a conserved endoplasmic reticulum membrane protein essential for glycosylphosphatidylinositol anchor synthesis in yeast. Mol. Biol. Cell 10:627-648.

Groeneveld, E., M. Kovač, and N. Mielenz. 2010. VCE User's Guide and Reference Manual. Version 6.0. Accessed July 15, 2013. ftp:// ftp.tzv.fal.de/pub/latest_vce/doc/vce6-manual-3.1-LETTER.pdf.

Haines, B. P., L. M. Wheldon, D. Summerbell, J. K. Heath, and P. W. J. Rigby. 2006. Regulated expression of FLRT genes implies a functional role in the regulation of FGF signalling during mouse development. Dev. Biol. 297:14-25.

Hansen, M., M. S. Lund, J. Pedersen, and L. G. Christensen. 2004. Gestation length in Danish Holsteins has weak genetic associations with stillbirth, calving difficulty, and calf size. Livest. Prod. Sci. 91:23-33. 
Hattori, K., I. Naguro, C. Runchel, and H. Ichijo. 2009. The roles of ASK family proteins in stress responses and diseases. Cell Commun. Signal. 7:9 http://dx.doi.org/10.1186/1478-811X-7-9.

Heins, B. J., L. B. Hansen, A. R. Hazel, A. J. Seykora, D. G. Johnson, and J. G. Linn. 2010. Birth traits of pure Holstein calves versus Montbeliarde-sired crossbred calves. J. Dairy Sci. 93:2293-2299.

Hofmann, C., M. Shepelev, and J. Chernoff. 2004. The genetics of Pak. J. Cell Sci. 117:4343-4354. http://dx.doi.org/10.1242/jcs.01392.

Holmberg, M., and L. Andersson-Eklund. 2006. Quantitative trait loci affecting fertility and calving traits in Swedish dairy cattle. J. Dairy Sci. 89:3664-3671.

Holstein Association USA. 2011. Linear type evaluations. Accessed Apr. 27, 2011. http://holstein.com/genetic_evaluations/ss_linear. html.

Horikoshi, M., H. Yaghootkar, D. O. Mook-Kanamori, U. Sovio, H R. Taal, B. J. Hennig, J. P. Bradfield, B. St. Pourcain, D. M. Evans, P. Charoen, M. Kaakinen, D. L. Cousminer, T. Lehtimäki, E. Kreiner-Møller, N. M. Warrington, M. Bustamante, B. Feenstra, D. J. Berry, E. Thiering, T. Pfab, S. J. Barton, B. M. Shields, M. Kerkhof, E. M. van Leeuwen, A. J. Fulford, Z. Kutalik, J. H. Zhao, M. den Hoed, A. Mahajan, V. Lindi, L.-K. Goh, J.-J. Hottenga, Y. Wu, O. T. Raitakari, M. N. Harder, A. Meirhaeghe, I. Ntalla, R. M. Salem, K. A. Jameson, K. Zhou, D. M. Monies, V. Lagou, M. Kirin, J. Heikkinen, L. S. Adair, F. S. Alkuraya, A. Al-Odaib, P. Amouyel, E. A. Andersson, A. J. Bennett, A. I. F. Blakemore, J. L. Buxton, J. Dallongeville, S. Das, E. J. C. de Geus, X. Estivill, C. Flexeder, P. Froguel, F. Geller, K. M. Godfrey, F. Gottrand, C. J. Groves, T. Hansen, J. N. Hirschhorn, A. Hofman, M. V. Hollegaard, D. M. Hougaard, E. Hyppönen, H M. Inskip, A. Isaacs, T. Jørgensen, C. Kanaka-Gantenbein, J. P. Kemp, W. Kiess, T. O. Kilpeläinen, N. Klopp, B. A. Knight, C. W. Kuzawa, G. McMahon, J. P. Newnham, H. Niinikoski, B. A Oostra, L. Pedersen, D. S. Postma, S. M. Ring, F. Rivadeneira, N. R. Robertson, S. Sebert, O. Simell, T. Slowinski, C. M. T. Tiesler, A. Tönjes, A. Vaag, J. S. Viikari, J. M. Vink, N. H. Vissing, N. J. Wareham, G. Willemsen, D. R. Witte, H. Zhang, J. Zhao, The Meta-Analyses of Glucose- and Insulin-related traits Consortium (MAGIC), J. F. Wilson, M. Stumvoll, A. M. Prentice, B. F. Meyer, E. R. Pearson, C. A. G. Boreham, C. Cooper, M. W. Gillman, G. V. Dedoussis, L. A. Moreno, O. Pedersen, M. Saarinen, K. L. Mohlke, D. I. Boomsma, S.-M. Saw, T. A. Lakka, A. Körner, R. J. F. Loos, K. K. Ong, P. Vollenweider, C. M. van Duijn, G. H. Koppelman, A. T. Hattersley, J. W. Holloway, B. Hocher, J. Heinrich, C. Power, M. Melbye, M. Guxens, C. E. Pennell, K. Bønnelykke, H. Bisgaard, J. G. Eriksson, E. Widén, H. Hakonarson, A. G. Uitterlinden, A. Pouta, D. A. Lawlor, G. D. Smith, T. M. Frayling, M. I. McCarthy, S. F. Grant, V. W. V. Jaddoe, M.-R. Jarvelin, N. J. Timpson, I. Prokopenko, R. M. Freathy, and the Early Growth Genetics (EGG) Consortium. 2013. New loci associated with birth weight identify genetic links between intrauterine growth and adult height and metabolism. Nat. Genet. 45:76-82. http://dx.doi. org/10.1038/ng.2477.

Hou, Y., G. E. Liu, D. M. Bickhart, M. F. Cardone, K. Wang, E.-S. Kim, L. K. Matukumalli, M. Ventura, J. Song, P. M. VanRaden, T. S. Sonstegard, and C. P. Van Tassell. 2011. Genomic characteristics of cattle copy number variations. BMC Genomics 12:127 http://dx.doi.org/10.1186/1471-2164-12-127.

Houmani, J. L., C. I. Davis, and I. K. Ruf. 2009. Growth-promoting properties of Epstein-Barr virus EBER-1 RNA correlate with ribosomal protein L22 binding. J. Virol. 83:9844-9853. http://dx.doi. org/10.1128/JVI.01014-09.

Huang, D. W., B. T. Sherman, and R. A. Lempicki. 2009. Bioinformatics enrichment tools: Paths toward the comprehensive functional analysis of large gene lists. Nucleic Acids Res. 37:1-13.

Jamrozik, J., J. Fatehi, G. J. Kistemaker, and L. R. Schaeffer. 2005. Estimates of genetic parameters for Canadian Holstein female reproduction traits. J. Dairy Sci. 88:2199-2208.

Janssens, V., and J. Goris. 2001. Protein phosphatase 2A: A highly regulated family of serine/threonine phosphatases implicated in cell growth and signalling. Biochem. J. 353:417-439.
Johanson, J. M., and P. J. Berger. 2003. Birth weight as a predictor of calving ease and perinatal mortality in Holstein cattle. J. Dairy Sci. $86: 3745-3755$.

Johanson, J. M., P. J. Berger, S. Tsuruta, and I. Misztal. 2011. A Bayesian threshold-linear model evaluation of perinatal mortality, dystocia, birth weight, and gestation length in a Holstein herd. J. Dairy Sci. 94:450-460.

Kent, W. J., C. W. Sugnet, T. S. Furey, K. M. Roskin, T. H. Pringle, A. M. Zahler, and D. Haussler. 2002. The Human Genome Browser at UCSC. Genome Res. 12:996-1006. http://dx.doi. org/10.1101/gr.229102.

Kneeland, J., C. Li, J. Basarab, W. M. Snelling, B. Benkel, B. Murdoch, C. Hansen, and S. S. Moore. 2004. Identification and fine mapping of quantitative trait loci for growth traits on bovine chromosomes 2, 6, 14, 19, 21, and 23 within one commercial line of Bos taurus. J. Anim. Sci. 82:3405-3414.

Koenen, E. P. C., and A. F. Groen. 1996. Genetic analysis of growth patterns of black and white dairy heifers. J. Dairy Sci. 79:495501.

Kolbehdari, D., Z. Wang, J. R. Grant, B. Murdoch, A. Prasad, Z. Xiu, E. Marques, P. Stothard, and S. S. Moore. 2008. A whole-genome scan to map quantitative trait loci for conformation and functional traits in Canadian Holstein bulls. J. Dairy Sci. 91:2844-2856.

Koshkoih, A. E., W. S. Pitchford, C. D. K. Bottema, A. P. Verbyla, and A. R. Gilmour. 2006. Mapping multiple QTL for birth weight using a mixed model approach. Comm. 20-17 in Proc. 8th World Congr. Genet. Appl. Livest. Prod., Belo Horizonte, MG, Brazil.

Kühn, C., J. Bennewitz, N. Reinsch, N. Xu, H. Thomsen, C. Looft, G. A. Brockmann, M. Schwerin, C. Weimann, S. Hiendleder, G. Erhardt, I. Medjugorac, M. Förster, B. Brenig, F. Reinhardt, R. Reents, I. Russ, G. Averdunk, J. Blümel, and E. Kalm. 2003. Quantitative trait loci mapping of functional traits in the German Holstein cattle population. J. Dairy Sci. 86:360-368.

Lee, J.-H., and T. T. Paull. 2007. Activation and regulation of ATM kinase activity in response to DNA double-strand breaks. Oncogene 26:7741-7748.

Legault, C. R., and R. W. Touchberry. 1962. Heritability of birth weight and its relationship with production in dairy cattle. J. Dairy Sci. 45:1226-1233.

Lin, L., T. G. Lesnick, D. M. Maraganore, and O. Isacson. 2009. Axon guidance and synaptic maintenance: Preclinical markers for neurodegenerative disease and therapeutics. Trends Neurosci. 32:142149. http://dx.doi.org/10.1016/j.tins.2008.11.006.

López de Maturana, E., X.-L. Wu, D. Gianola, K. A. Weigel, and G. J. M. Rosa. 2009. Exploring biological relationships between calving traits in primiparous cattle with a Bayesian recursive model. Genetics 181:277-287.

Maltecca, C., K. A. Gray, K. A. Weigel, J. P. Cassady, and M. Ashwell. 2011. A genome-wide association study of direct gestation length in US Holstein and Italian Brown populations. Anim. Genet. 42:585-591. http://dx.doi.org/10.1111/j.1365-2052.2011.02188.x.

Maltecca, C., K. A. Weigel, H. Khatib, M. Cowan, and A. Bagnato 2008. Whole-genome scan for quantitative trait loci associated with birth weight, gestation length and passive immune transfer in a Holstein $\times$ Jersey crossbred population. Anim. Genet. 40:27-34.

Maltecca, C., K. A. Weigel, H. Khatib, M. Cowan, and A. Bagnato. 2009. Whole-genome scan for quantitative trait loci associated with birth weight, gestation length and passive immune transfer in a Holstein $\times$ Jersey crossbred population. Anim. Genet. 40:27-34.

Maydan, G., I. Noyman, A. Har-Zahav, Z. Ben Neriah, M. PasmanikChor, A. Yeheskel, A. Albin-Kaplanski, I. Maya, N. Magal, E. Birk, A. J. Simon, A. Halevy, G. Rechavi, M. Shohat, R. Straussberg, and L. Basel-Vanagaite. 2011. Multiple congenital anomalies-hypotonia-seizures syndrome is caused by a mutation in PIGN. J. Med. Genet. 48:383-389. http://dx.doi.org/10.1136/ jmg.2010.087114.

McDermott, J. J., O. B. Allen, S. W. Martin, and D. M. Alves. 1992. Patterns of stillbirth and dystocia in Ontario cow-calf herds. Can. J. Vet. Res. 56:47-55.

Meijering, A. 1984. Dystocia and stillbirth in cattle-A review of causes, relations and implications. Livest. Prod. Sci. 11:143-177. 
Meyer, C. L., P. J. Berger, J. R. Thompson, and C. G. Sattler. 2001. Genetic evaluation of Holstein sires and maternal grandsires in the United States for perinatal survival. J. Dairy Sci. 84:1246-1254.

Miesenberger, J. 1997. Zuchtzieldefinition und Indexselektion für die österreichische Rinderzucht [Definition of the aggregate genotype and a selection index for the Austrian cattle]. PhD Diss. Universität für Bodenkultur, Vienna, Austria.

Misztal, I., S. Tsuruta, T. Strabel, B. Auvray, T. Druet, and D. H. Lee. 2002. BLUPF90 and related programs (BGF90). Comm. No. 28-07 in Proc. 7th World Congr. Genet. Appl. Livest. Prod., Montpellier, France.

Müller, P.-S., R. Schulz, S. Maretto, I. Costello, S. Srinivas, E. Bikoff, and E. Robertson. 2011. The fibronectin leucine-rich repeat transmembrane protein Flrt2 is required in the epicardium to promote heart morphogenesis. Development 138:1297-1308. http://dx.doi. org $/ 10.1242 /$ dev.059386.

Muntoni, F., S. Torelli, and A. Ferlini. 2003. Dystrophin and mutations: One gene, several proteins, multiple phenotypes. Lancet Neurol. 2:731-740.

Nakashiba, T., T. Ikeda, S. Nishimura, K. Tashiro, T. Honjo, J. G. Culotti, and S. Itohara. 2000. Netrin-G1: A novel glycosyl phosphatidylinositol-linked mammalian netrin that is functionally divergent from classical netrins. J. Neurosci. 20:6540-6550.

Norman, H. D., J. R. Wright, M. T. Kuhn, S. M. Hubbard, J. B. Cole, and P. M. VanRaden. 2009. Genetic and environmental factors that affect gestation length in dairy cattle. J. Dairy Sci 92:2259-2269.

Olson, K. M., B. G. Cassell, A. J. McAllister, and S. P. Washburn. 2009. Dystocia, stillbirth, gestation length, and birth weight in Holstein, Jersey, and reciprocal crosses from a planned experiment. J. Dairy Sci. 92:6167-6175.

Pausch, H., K. Flisikowski, S. Jung, R. Emmerling, C. Edel, K.-U. Götz, and R. Fries. 2011. Genome-wide association study identifies two major loci affecting calving ease and growth-related traits in cattle. Genetics 187:289-297.

Pfaeffle, R. W., C. S. Hunter, J. J. Savage, M. Duran-Prado, R. D. Mullen, Z. P. Neeb, U. Eiholzer, V. Hesse, N. G. Haddad, H. M. Stobbe, W. F. Blum, J. F. W. Weigel, and S. J. Rhodes. 2008. Three novel missense mutations within the $\mathrm{LHX}_{4}$ gene are associated with variable pituitary hormone deficiencies. J. Clin. Endocrinol. Metab. 93:1062-1071. http://dx.doi.org/10.1210/ jc. $2007-1525$.

Pfeffer, P. L., B. Sisco, M. Donnison, J. Somers, and C. Smith. 2007. Isolation of genes associated with developmental competency of bovine oocytes. Theriogenology 68(Suppl. 1):S84-S90. http:// dx.doi.org/10.1016/j.theriogenology.2007.03.016.

Philipsson, J., J. L. Foulley, J. Lederer, T. Liboriussen, and A. Osinga. 1979. Sire evaluation standards and breeding strategies for limiting dystocia and stillbirth. Report of an E.E.C./E.A.A.P. working group. Livest. Prod. Sci. 6:111-127.

Pryce, J. E., B. J. Hayes, S. Bolormaa, and M. E. Goddard. 2011. Polymorphic regions affecting human height also control stature in cattle. Genetics 187:981-984. http://dx.doi.org/10.1534/ genetics.110.123943.

Purfield, D. C., D. G. Bradley, J. F. Kearney, and D. P. Berry. 2014. Genome-wide association study for calving traits in Holstein-Friesian dairy cattle. Animal 8:224-235. http://dx.doi.org/10.1017/ S175173111300195X.

Qanbari, S., D. Gianola, B. Hayes, F. Schenkel, S. Miller, S. Moore, G. Thaller, and H. Simianer. 2011. Application of site and haplotypefrequency based approaches for detecting selection signatures in cattle. BMC Genomics 12:318 http://dx.doi.org/10.1186/14712164-12-318.

Quinlan, A. R., and I. M. Hall. 2010. BEDTools: A flexible suite of utilities for comparing genomic features. Bioinformatics 26:841842.

R Development Core Team. 2010. R: A Language and Environment for Statistical Computing. R Foundation for Statistical Computing, Vienna, Austria.

Ren, G., H. Chen, L. Z. Zhang, X. Y. Lan, T. B. Wei, M. J. Li, Y. J. Jing, C. Z. Lei, and J. Q. Wang. 2010. A coding SNP of LHX4 gene is associated with body weight and body length in bovine. Mol. Biol. Rep. 37:417-422. http://dx.doi.org/10.1007/s11033009-9486-6.

Sahana, G., B. Guldbrandtsen, and M. S. Lund. 2011. Genome-wide association study for calving traits in Danish and Swedish Holstein cattle. J. Dairy Sci. 94:479-486.

Schnabel, R. D., T. S. Sonstegard, J. F. Taylor, and M. S. Ashwell. 2005. Whole-genome scan to detect QTL for milk production, fertility and functional traits in two US Holstein families. Anim. Genet. 36:408-416.

Schutz, M. M. 1994. Genetic evaluation of somatic cell scores for United States dairy cattle. J. Dairy Sci. 77:2113-2129.

Seidenspinner, T., J. Tetens, D. Habier, J. Bennewitz, and G. Thaller. 2011. The placental growth factor (PGF) - A positional and functional candidate gene influencing calving ease and stillbirth in German dairy cattle. Anim. Genet. 42:22-27.

Simmons, D., and B. Seed. 1988. Isolation of a cDNA encoding CD33, a differentiation antigen of myeloid progenitor cells. J. Immunol. 141:2797-2800.

Smith, S. B., H.-Q. Qu, N. Taleb, N. Y. Kishimoto, D. W. Scheel, Y. Lu, A.-M. Patch, R. Grabs, J. Wang, F. C. Lynn, T. Miyatsuka, J. Mitchell, R. Seerke, J. Désir, S. V. Eijnden, M. Abramowicz, N. Kacet, J. Weill, M.-È. Renard, M. Gentile, I. Hansen, K. Dewar, A. T. Hattersley, R. Wang, M. E. Wilson, J. D. Johnson, C. Polychronakos, and M. S. German. 2010. Rfx6 directs islet formation and insulin production in mice and humans. Nature 463:775-780. http://dx.doi.org/10.1038/nature08748.

Smith, S. L., R. E. Everts, L.-Y. Sung, F. Du, R. L. Page, B. Henderson, S. L. Rodriguez-Zas, T. L. Nedambale, J.-P. Renard, H. A. Lewin, X. Yang, and X. C. Tian. 2009. Gene expression profiling of single bovine embryos uncovers significant effects of in vitro maturation, fertilization and culture. Mol. Reprod. Dev. 76:38-47.

Sokal, R. R., and F. J. Rohlf. 1995. Biometry: The Principles and Practice of Statistics in Biological Research. 3rd ed. W. H. Freeman and Co., New York, NY.

Swali, A., and D. C. Wathes. 2006. Influence of the dam and sire on size at birth and subsequent growth, milk production and fertility in dairy heifers. Theriogenology 66:1173-1184.

Thomasen, J. R., B. Guldbrandtsen, P. Sørensen, B. Thomsen, and M. S. Lund. 2008. Quantitative trait loci affecting calving traits in Danish Holstein cattle. J. Dairy Sci. 91:2098-2105.

Thompson, J. R., A. E. Freeman, and P. J. Berger. 1980. Relationship of dystocia transmitting ability with type and production transmitting ability in Holstein bulls. J. Dairy Sci. 63:1462-1464.

Uitto, J. 2005. The gene family of ABC transporters - Novel mutations, new phenotypes. Trends Mol. Med. 11:341-343.

Utsunomiya, Y. T., A. S. do Carmo, R. Carvalheiro, H. H. R. Neves, M. C. Matos, L. B. Zavarez, A. M. Pérez O'Brien, J. Sölkner, J. McEwan, J. B. Cole, C. P. Van Tassell, F. S. Schenkel, M. V. G. B. da Silva, L. R. Porto Neto, T. S. Sonstegard, and J. F. Garcia. 2013. Genome-wide association study for birth weight in Brazilian Nellore cattle (Bos taurus indicus) points to previously described orthologous genes affecting human and bovine height. BMC Genet. 14:52 http://dx.doi.org/10.1186/1471-2156-14-52

Van Tassell, C. P., G. R. Wiggans, and I. Misztal. 2003. Implementation of a sire-maternal grandsire model for evaluation of calving ease in the United States. J. Dairy Sci. 86:3366-3373.

VanRaden, P. M. 2008. Efficient methods to compute genomic predictions. J. Dairy Sci. 91:4414-4423.

VanRaden, P. M., J. R. O'Connell, G. R. Wiggans, and K. A. Weigel. 2011a. Genomic evaluations with many more genotypes. Genet. Sel. Evol. 43:10.

VanRaden, P. M., K. M. Olson, G. R. Wiggans, J. B. Cole, and M. E. Tooker. 2011b. Genomic inbreeding and relationships among Holsteins, Jerseys, and Brown Swiss. J. Dairy Sci. 94:5673-5682.

VanRaden, P. M., A. H. Sanders, M. E. Tooker, R. H. Miller, H. D. Norman, M. T. Kuhn, and G. R. Wiggans. 2004. Development of a national genetic evaluation for cow fertility. J. Dairy Sci. $87: 2285-2292$. 
VanRaden, P. M., and G. R. Wiggans. 1995. Productive life evaluations: Calculation, accuracy, and economic value. J. Dairy Sci. 78:631-638.

Varki, A., and T. Angata. 2006. Siglecs-The major subfamily of Itype lectins. Glycobiology 1:1R-27R. http://dx.doi.org/10.1093/ glycob/cwj008.

Venables, J. P., C. Vernet, S. L. Chew, D. J. Elliott, R. B. Cowmeadow, J. Wu, H. J. Cooke, K. Artzt, and I. C. Eperon. 1999. TSTAR/ÉTOILE: A novel relative of SAM68 that interacts with an RNA-binding protein implicated in spermatogenesis. Hum. Mol. Genet. 8:959-969.

Villa, A., D. Strina, A. Frattini, S. Faranda, P. Macchi, P. Finelli, F. Bozzi, L. Susani, N. Archidiacono, M. Rocchi, and P. Vezzoni. 1996. The ZNF75 zinc finger gene subfamily: Isolation and mapping of the four members in humans and great apes. Genomics 35:312-320.

vit. 2013. Estimation of breeding values for milk production traits, somatic cell score, conformation, productive life and reproduction traits in German dairy cattle. Accessed Jan. 17, 2013. http://www.vit. de/fileadmin/user_upload/vit-fuers-rind/zuchtwertschaetzung/ milchrinder-zws-online/Zws_Bes_eng.pdf.

Vitelli, F., M. Piccini, F. Caroli, B. Franco, A. Malandrini, B. Pober, J. Jonsson, V. Sorrentino, and A. Renieri. 1999. Identification and characterization of a highly conserved protein absent in the Alport syndrome (A), mental retardation (M), midface hypoplasia $(\mathrm{M})$, and elliptocytosis (E) contiguous gene deletion syndrome (AMME). Genomics 55:335-340.

Waurich, B., M. Wensch-Dorendorf, J. B. Cole, and H. H. Swalve. 2011. Genetic evaluations for birth weight: A comparison of con- tinuous and discrete definitions of birth weight under varying accuracies of recording. Session 36:2, S. 217 in Proc. Annu. Mtg. EAAP, Stavanger, Norway. Wageningen Academic Publishers, Wageningen, the Netherlands.

Waurich, B., M. Wensch-Dorendorf, R. Schafberg, B. Rudolphi, and H. H. Swalve. 2010. Relationships between conformation traits and traits of the calving complex in dairy cows. Paper no. 0386 in Proc. 9th World Congr. Genet. Appl. Livest. Prod., Leipzig, Germany.

Wei, L., W. Roberts, L. Wang, M. Yamada, S. Zhang, Z. Zhao, S. A. Rivkees, R. J. Schwartz, and K. Imanaka-Yoshida. 2001. Rho kinases play an obligatory role in vertebrate embryonic organogenesis. Development 128:2953-2962.

Wickham, H. 2009. ggplot2: Elegant Graphics for Data Analysis. Springer, New York, NY.

Yu, J., G. Pressoir, W. H. Briggs, I. V. Bi, M. Yamasaki, J. F. Doebley, M. D. McMullen, B. S. Gaut, D. M. Nielsen, J. B. Holland, S. Kresovich, and E. S. Buckler. 2006. A unified mixed-model method for association mapping that accounts for multiple levels of relatedness. Nat. Genet. 38:203-208.

Zhang, R., F. Yao, F. Gao, and A. B. Abou-Samra. 2012. Nrac, a novel nutritionally-regulated adipose and cardiac-enriched gene. PLoS ONE 7:e46254 http://dx.doi.org/10.1371/journal.pone.0046254.

Zimin, A. V., A. L. Delcher, L. Florea, D. R. Kelley, M. C. Schatz, D. Puiu, F. Hanrahan, G. Pertea, C. P. Van Tassell, T. S. Sonstegard, G. Marçais, M. Roberts, P. Subramanian, J. A. Yorke, and S. L. Salzberg. 2009. A whole-genome assembly of the domestic cow, Bos taurus. Genome Biol. 10:R42 http://dx.doi.org/10.1186/gb2009-10-4-r42. 